\title{
IDENTIFYING AND MAPPING OF SLUMS IN PUNE CITY USING GEOSPATIAL TECHNIQUES
}

\author{
N. Mundhe \\ International Institute for Population Sciences (IIPS), Mumbai and \\ Department of Geography, Sir Parashurambhau College, Pune, India - mundhenitin8@gmail.com
}

Commission V, WG V/7 \& Commission IV, WG IV/6

KEY WORDS: Environment, Geospatial, Land Use, Migration, Slum, Urban

\begin{abstract}
:
In India, rapid growth of slums in urban areas, especially in metropolitan cities, has become a major problem for the planners and decision-makers. The slum expansion is mainly due to the rural-urban migration and pressure of the population on un-used, unprotected, and un-suitable public land. It leads to many issues like poverty, unemployment, lack of access to clean water, lack of durable housing, traffic congestion, environmental pollution, insufficient living area, inadequate sanitation, scarcity of land, inappropriate land use, skyrocketing land value and insecure tenure, etc. Planning controls are usually ineffective in slum areas due to lack of timely information and people having little regard for such things in the absence of any other alternative. In most of the municipal bodies, proper updated information/map of slums are not available, which, create a problem in the decision-making process. Thus, there is an imperative need to resolve above-mentioned issues with the help of Geospatial techniques. This paper aims to identify and mapping of slums in Pune City using Geospatial techniques. The slums were identified based on high-resolution satellite images such as Resourcesat-2 (LISS-IV) data with the help of visual interpretation and standard image processing techniques, i.e., image rectification, enhancement, and classification. Afterward, the database was created and labeled with the help of the GIS tool. In Pune, there is around 40 percent of the urban population resides in slums. Such a large proportion of slum population also adds to the burden of already scarce resources and on overall urban infrastructure. The entire slum population of the city was accommodated in a total of 477 slums of which 238 and 239 were declared and undeclared slums respectively. The most of the slums in Pune mainly occurred in the central part due to natural increases as well as migration. But, the peripheral areas it's happen due to vacant land/open areas along to river, canal, railway line and hill slope. The study reveals that more than 200 slums are located near environmentally sensitive areas and encroachment activities are increased in southern part of the city i.e., Ambegaon Bk., Vithhal Nagar and Warje areas.
\end{abstract}

\section{INTRODUCTION}

Urbanization is the physical growth of urban areas, which result in population growth, an increase of built-up area, high density of population, and also the psychological stage of the urban way of life. The urban population in the world is generally rising. It is expected to increase by 72 percent by 2050, from 3.6 billion in 2011 to 6.3 billion in 2050 . By 2050, it is predicted that 64.1 percent and 85.9 percent population will be urbanized in developing and developed world respectively (United Nations, 2011). Urban population in India has increased more than six times during the last 60 years from 62.44 million in 1951 to 377.1 million in 2011. Presently, it is 31.16 percent of the total population (Census of India, 2011). In India's three urban agglomerations viz. Greater Mumbai, Delhi, and Kolkata have crossed the 10 million mark in population, while the number of million-plus cities has been increased from 5 in 1951 to 53 in 2011 (Census of India, 2011). According to Government sources, a total of 65.49 million population living in 13.9 million households have been enumerated in slum reporting towns (2613) among States and Union Territories. The slum population enumerated was 17.4 percent of the total urban population of all the States and Union Territories in 2011 (Census of India, 2011).

The acute problem of slum formation is found not only in the big cities but, also in medium and small cities/towns in India due to rapid urbanization, poor housing planning and increasing migration of people from rural to urban areas (Jitendra Kumar, 2014). This has increased the demand for affordable housing in urban areas. Hence, slums have formed mainly because of the inability of city governments to plan and provide affordable housing for low-income segments of the urban population (Ooi and Phua, 2007). Such dwellings are usually built in marginal areas such as along natural drainage channels, railway lines, hillsides, etc. Planning controls are usually ineffective due to lack of timely information and people having little regard for the absence of any other alternative (Kombe, 2005; Maktav and Erber, 2005). In most of the municipal bodies, proper updated information/map of slums are not available, which, create a problem in the decision-making process. Thus, there is an urgent need to adopt modern technology like remote sensing and Geographical Information System (GIS) for resolving the problem of slum areas (Sori, 2012).

\section{STUDY AREA}

Pune is the second-largest city in Maharashtra and one of the eight-mega cities of India regarding population, with a population growth of 7.8 percent during 2001-11 (Government of India, 2013). Pune city lies between latitudes $18^{\circ} 25^{\prime} \mathrm{N}$ and $18^{\circ} 37^{\prime} \mathrm{N}$ and longitudes between $73^{\circ} 44^{\prime} \mathrm{E}$ and $73^{\circ} 57^{\prime} \mathrm{E}$, and the geographical area is around $250.56 \mathrm{sq}$. $\mathrm{Km}$ with a population of about 3.1 million composed of 76 general electoral wards. Based on Census of India 2011, these wards are converted under 14 administrative wards by Pune Municipal Corporation (Figure 1). The city boasts of a strong heritage and culture with picturesque historical, religious, and natural zones and hence is called the 'culture capital' of Maharashtra. Further, the city also processes the strengths in the educational sector with many educational institutes and a well-skilled labour force, for which it is considered as the "Oxford of the East."

Pune attracts thousands of immigrants due to multiple variants of economic activities and most of them falling in the category 
of lower strata forming the poor or low-income group, who are forced to live in slums or slum-like conditions due to poor affordability. In 1951 the slum population was about 8 percent of the city's population, which according to slum department of PMC, in 2011 gradually increased up to 40 percent (Figure 2). Such a large proportion of slum population also adds to the burden of already scarce resources and on overall urban infrastructure.

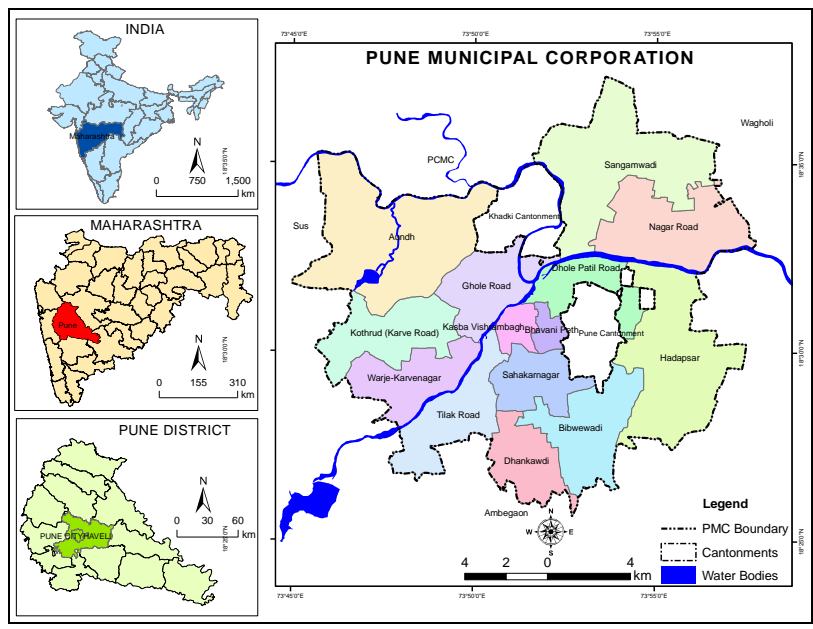

Figure 1. Location Map

\section{RESEARCH QUESTION}

Where are the emerging and vulnerable slum areas in a city?

\section{OBJECTIVE}

The main objective of the present study is to identify and mapping of slum areas in Pune City using Geospatial techniques like Remote Sensing and Geographic Information System (GIS) technique for sustainable urban planning.

\section{MATERIALS AND METHODS}

Data required for the current study is collected from various sources: governmental institutions, published reports, books, research journals, and library resources. The high resolution $(5.8 \mathrm{~m})$ remote sensing data, Resourcesat-2 (LISS IV) acquired in November 2016 is procured from National Remote Sensing Centre (NRSC), Hyderabad for identifying and mapping of slum areas. ASTER Global Digital Elevation data collected from USGS Website for preparation of 3-D map and relief map of the study area (Table 1).

Subsequently, Survey of India (SOI) toposheets at 1:50,000 scale was used for the extraction of thematic layers: contours, drainage network, water bodies, roads, and rail network, forest areas and administrative boundaries, etc. Demographic details of the study area were obtained from the Census of India and various reports of Pune city, which is useful for the preparation of a demographic map. Ward map and administrative boundaries of the study area was collected from Pune Municipal Corporation (PMC).

In methodology involved several steps, i.e., image preprocessing, image classification, ground truth data collection and verification, accuracy assessment, post-classification, and post-processing (Joshi et al., 2002; Sur, 2004).

\begin{tabular}{|c|c|}
\hline Segment:Pune city & Sources \\
\hline $\begin{array}{l}\text { Topographical (OSM) Maps : } \\
\text { E43H14 \& E43H15 surveyed in } \\
\text { 2011, Scale 1:50,000 }\end{array}$ & - Survey of India (SOI) \\
\hline $\begin{array}{ll}\text { Satellite Data - } \\
\text { i) } \\
\text { Resourcesat 2- LISS IV - } \\
\text { (2016) } \\
\text { ii) } \\
\text { ASTER GDEM (2011) }\end{array}$ & $\begin{array}{l}\text { - NRSC, Hyderabad } \\
\text { - https://earthexplorer.usgs.gov }\end{array}$ \\
\hline $\begin{array}{ll}\text { Other data - } \\
\text { i) Slum Population, } \\
\text { ii) Slum Distribution } \\
\text { (declared and undeclared } \\
\text { slum) etc. } \\
\text { iii) } \\
\text { Ward Boundary Map }\end{array}$ & $\begin{array}{l}\text { - Primary Census Abstract for } \\
\text { Slum, Census of India-2011 } \\
\text { - ESR 2016-17, PMC } \\
\text { - Revised City Development } \\
\text { Plan for Pune-2041 } \\
\text { - Pune Municipal Corporation } \\
\text { (PMC) office } \\
\end{array}$ \\
\hline
\end{tabular}

Table 1. Spatial and Non-spatial data

\subsection{Image Pre-processing}

Image pre-processing involves scanning, geo-referencing, and digitization topographical maps, satellite images, and other base maps. Firstly, topographical maps, e.g., E43H14 and E43H1415 scale 1:50,000 were geo-referenced using the UTM projection system and digitized thematic layers such as ward boundaries, road, railway line, river, forest, population density, declared and undeclared slums, etc. The remotely sensed image acquired by the Resourcesat 2 (LISS IV) sensor with a spatial resolution of $5.8 \mathrm{~m}$ in November 2016, was used for visually interpreting the land use/land cover. Images were processed using slandered techniques like rectification, enhancement, band extraction, restoration, and image subset.

\subsection{Image Classification}

Image classification technique is based on spectral reflectance values with an assumption of the training data being normally distributed (Behanzin et al., 2015). The hybrid image classification approach effectively integrates supplementary information into the classification process. The classification scheme of land LU/LC is based on the classification scheme developed by NRSC/ISRO in 2015 (Arveti et al., 2016). As per this scheme, remote sensing image was classified into mainly two classes, i.e., slums and non-slums areas.

\subsection{Ground Truth Verification}

Ground truth verification was done in problematic areas in the classified map of land use/ land cover. Repetitive fieldwork was conducted using Global Positioning System (GPS) instrument.

\subsection{Accuracy Assessment}

Accuracy assessment was conducted based on the visual interpretation method supported by ground truth data collected in the fieldwork. Thus, to find out how accurate and useful the resulting classification, it is helpful to conduct an accuracy assessment, primarily, when resulting maps are going to be used for the decision-making process (Jensen, 2004). Quality measures derived from the error matrix, which is the crosstabulation of referenced and classified data (Congalton and Green, 2008). It is used to assess the detailed image in terms of user's, producer's and overall accuracy as well as Kappa coefficient (Cohen, 1960; Lillesand et al., 2000; Jensen, 2005).

\subsection{Post-classification}


Post-classification process refers to the process of removing the error and improving the quality of the classified output. Furthermore, a post-classification smoothing was applied for present work. Corrections and modifications of doubtful areas are done based on ground intelligence, and the outline is given to final slum map of the study area is prepared.

\subsection{Post-processing}

The final step is post-processing that contains to prepare the output of the final map, which resulted from the classified image. Slum and non-slum areas of Pune city extracted from the various sources such as classified image, Google Earth image, and georeferenced topographical map. These extracted layers were overlaid on the administrative boundary layer. Finally, detailed mapping of a slum area in Pune city was prepared with the help of mined classified layer.

In addition to that, the slum map of the study area was overlaid on the 3-D model to find out which slums are vulnerable to environmentally sensitive areas. These findings of the research work are expected to help sustainable urban planning and measures to control future slum growth as well as minimizing impacts on the environment.

\section{RESULTS AND DISCUSSIONS}

\subsection{Status of Slums}

Pune attracts thousands of immigrants due to multiple variants of economic activities and most of them falling in the category of lower strata forming the poor or low-income group, who are forced to live in slums. The slum population in Pune city is more than 1.2 million people accommodating in a total number of 477 slums acquiring an area of 525 hectare which calculates to a density of 2398.5 persons per hectare (ESR, 2016-17). The density in slums (person/Sq.km) is more than six times that of the overall density prevailing in the rest of the city. As per the secondary information collected from Pune Municipal Corporation, there are 477 slums out of which 238 (50\%) are declared and 239 (50\%) being undeclared slums (Figure 2).

In Pune city, only 238 slums acquired the privilege of being declared as slums proclaiming that 50 percent of the city's population resides in declared slums. However, by the various report, it has been revealed that not only 238 slums have a better provision of the basic services by PMC, but also the rest non-declared slums are being served by the corporation.

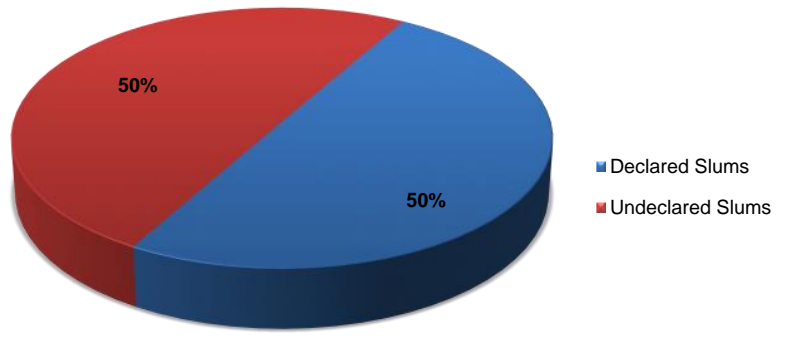

Source: MASHAL, 2011 and ESR, 2016-17 Figure 2. Slums in Pune City

The number of slums in each ward varies depending upon many factors like employment opportunities, transport connectivity, vacant land or open land, etc. At present, the Bhavani Peth ward shows the maximum number of slum pockets, i.e., 62 followed by Dhole Patil Road, Hadapsar and Sangamwadi wards (Figure 3). It is also seen that the number of undeclared slums in these wards is also more than the declared slums. The least number of slum pockets is noticed in the Dhankawadi ward.

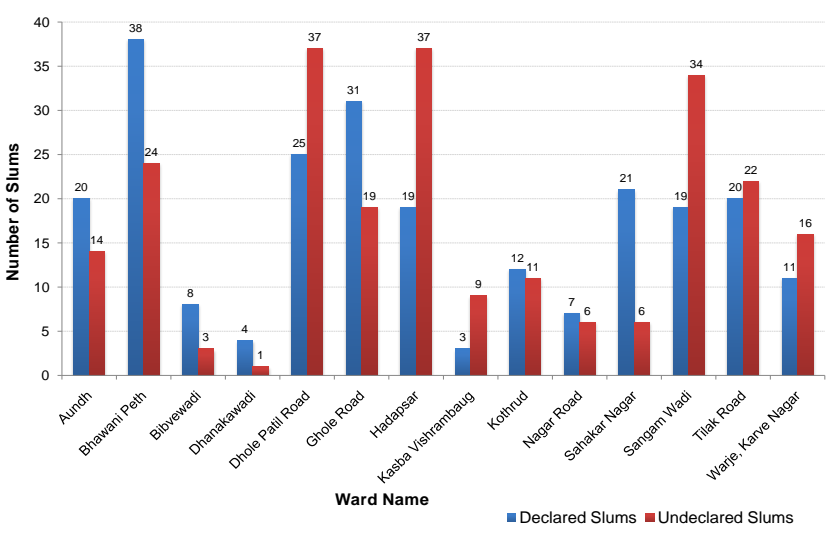

Source: MASHAL, 2011 and ESR, 2016-17

Figure 3. Ward-wise Slum Pockets in Pune

\subsection{Slums Population}

The growth of slums in Pune city is phenomenal; from a share of 8 percent of the total population in 1951, it has raised up to approximately 40 percent in the year 2011 (Figure 4). The main reason for such a significant increase is unaffordable pricing of house costs and sturdy economic activity in city jurisdiction. Such a large proportion of slum population also adds to the burden of already scarce resources and on overall urban infrastructure.

Figure 5 indicates that the growth of the slum population was higher than that of the total population. It is observed that during 1971, the annual growth in slum population was about 10 percent against the total growth in population at 3.5 percent due to the rural conditions, particularly, in 1966-67 and 197273 Maharashtra faced severe droughts. It is likely that these brought a large number of migrants to Pune in search of livelihood. This trend continued further but at a slower pace and picked up again in 2001.

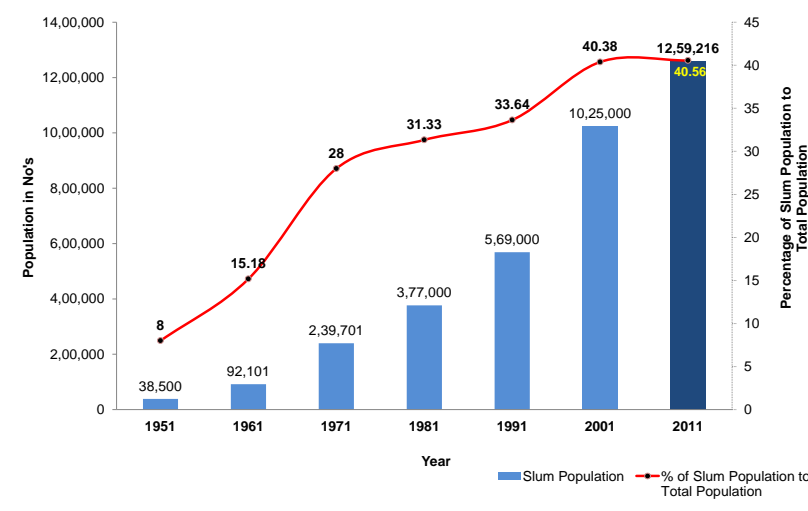

Source: Compiled from ESR, 2016-17

Figure 4. Growth of Slum Population 


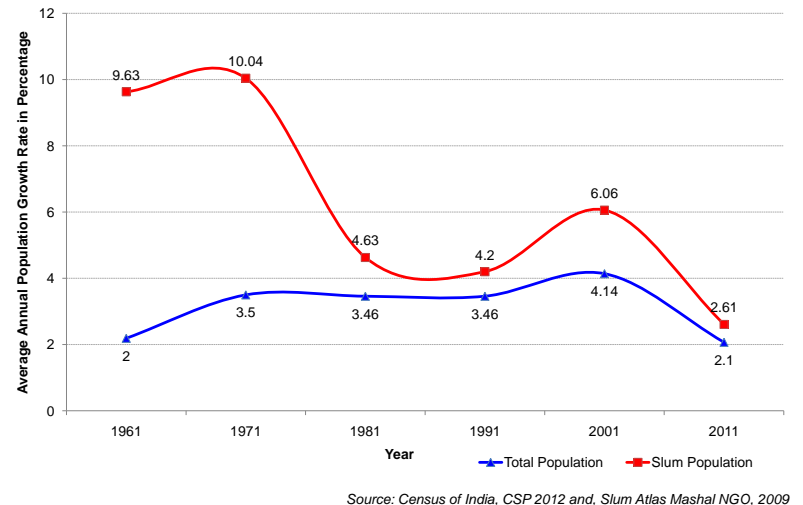

Source: Census of India, 2011 and ESR, 2016-2017

Figure 5. Annual Average Population Growth Rate

\subsection{Slum Population (Ward-wise)}

The proportion of Pune's population, which lives in slums, is high. The slum population in Pune city has continuously increased from 38,500 in 1951 to $12,59,216$ in 2011. This increase in the slum population has created pressure on essential urban services. Thus, there is a need to provide essential services in the slums and raise the standard of living. In Pune, there are 477 slum pockets spread over the 14 administrative wards depending upon many factors like proximity to the main road and workplace, availability of water resources, employment opportunities, and vacant land lying unused, etc. Within these slums, around 238 slums are declared, and 239 slums are undeclared. These slums are located in all areas of city frontier.

At present, the Ghole Road ward shows the maximum percentage of slum population, i.e., 49 percent followed by Dhole Patil Road and Sangamwadi ward, i.e., 46 percent and 45 percent respectively. The least number of slum populations is noticed in Dhankawadi ward with 2 percent followed by Kasaba-Vishrambaugwada and Bibvewadi ward (Figure 6).

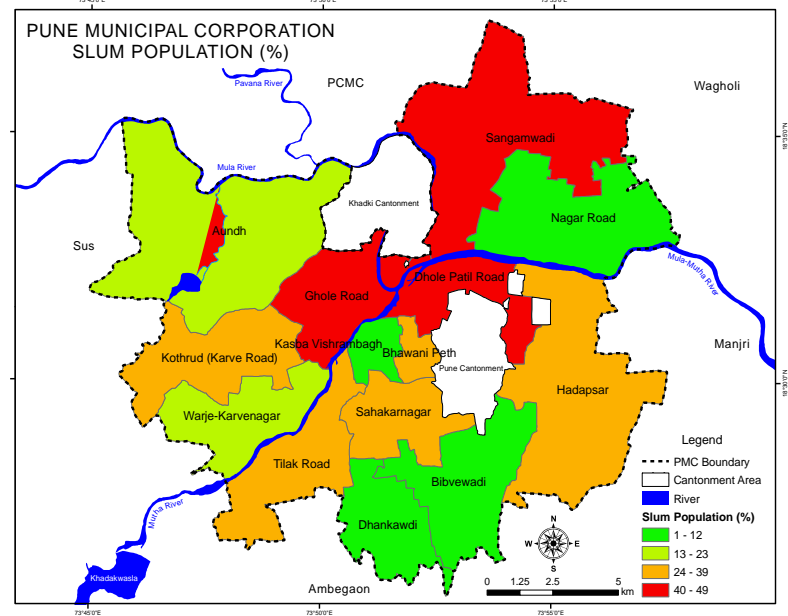

Figure 6. Ward-wise Slum Population

\subsection{Slum Population Density}

The total area occupied by the slums in Pune is approximately 525 hectares. Out of that, Sangamwadi ward has the highest slum area amongst all the wards, i.e., 85.99 hectares. The slum population density is calculated by dividing the slum population of the ward by area occupied by the slum in the ward. The density in slums (person/hectare) is about six times that of the overall density prevailing in the rest of the city. The highest density is in the Dhankawadi ward, wherein the slum density is 2217 persons per hectare, followed by Sahakar Nagar (2122) and Bhavani Peth (2058) ward (Figure 7). This highlights the amount of pressure on the infrastructure services and the living conditions of the slum residents. Such a high slum density also indicates high health and social costs. Based on the analysis, observed that around 50 percent of the slum population lives in unauthorized or not notified areas of the city.

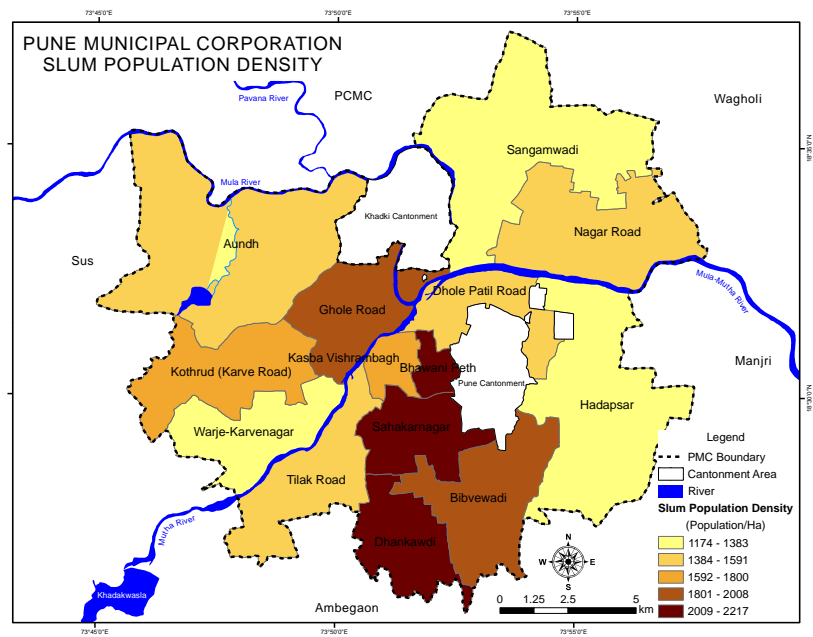

Figure 7. Ward-wise Slum Population Density

\subsection{Slum Tenement Density}

A tenement is a multi-occupancy building of any type, but mainly a run-down apartment building or slum building. The tenement density is calculated by dividing the number of slum structure of the ward by the area occupied by the slum in the ward. The maximum tenement density is found in the Dhankawadi ward, i.e. 444 tenements per hectare followed by Bibvewadi (424) and Kasba-Vishrambaugwada (412) ward (Figure 8 ). In both cases, Dhankawadi ward shows high slum population density as well as tenement density.

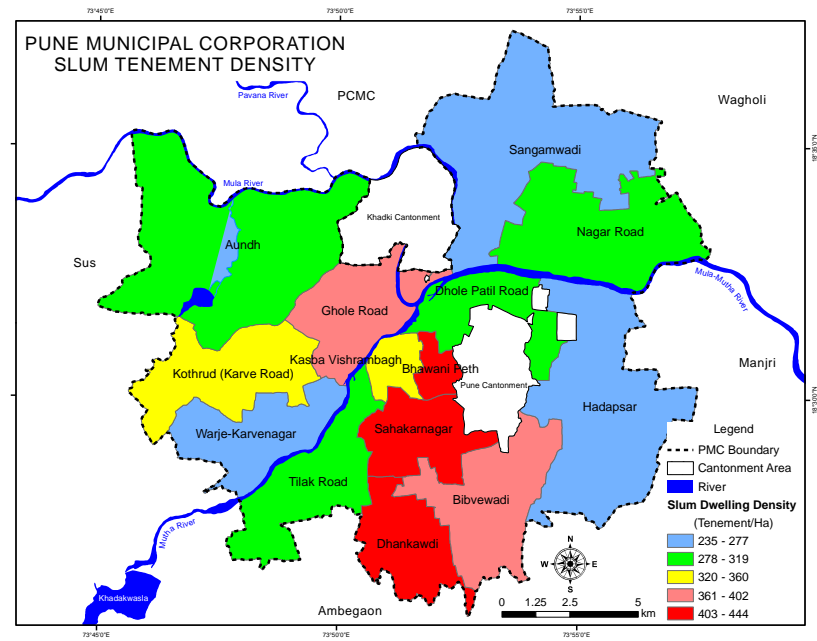

Figure 8, Ward-wise Slum Tenement Density 


\subsection{Location of Slums in Pune}

In Pune city there are 477 slums, out of that $356(74.63 \%)$ slums are located on private land and reaming $121(25.37 \%)$ slums are located on non-private land (Table 2). A very short proportion of slums are located on the land of Maharashtra Housing and Area Development Authority (MHADA), i.e., 3 slums (0.63\%), Central Government (0.84\%) and Pune Municipal Corporation (1.68\%). A much higher proportion of the newer slums have come upon the railway track and along with the water bodies. Nearly (7\%) of registered and unregistered slums are located along the railway line (Figure 9). Slums have encroached rapidly public as well as private land. They are located mainly on the land judged unsuitable or unattractive for real estate development such as along natural drainage channels, railway lines, hillsides, etc. In Pune city, central areas of city found slums due to natural increases as well as quick migration from rural to urban areas. But, the peripheral areas it happens due to vacant land or open areas along the river, canal and hillslope.

\begin{tabular}{|c|l|c|c|c|c|c|c|c|}
\hline \multirow{2}{*}{$\begin{array}{l}\text { Sr } \\
\text { No }\end{array}$} & $\begin{array}{l}\text { Administr } \\
\text { ative } \\
\text { Wards }\end{array}$ & $\begin{array}{c}\text { CM } \\
\text { C }\end{array}$ & $\begin{array}{c}\text { Stat } \\
\text { e } \\
\text { Gov } \\
\text { t. }\end{array}$ & $\begin{array}{c}\text { Mhad } \\
\text { a }\end{array}$ & $\begin{array}{c}\text { Railw } \\
\text { ay }\end{array}$ & $\begin{array}{c}\text { Centra } \\
\text { G } \\
\text { Govt. }\end{array}$ & $\begin{array}{c}\text { Priv } \\
\text { ate }\end{array}$ & $\begin{array}{c}\text { Total } \\
\text { No. of } \\
\text { Slums }\end{array}$ \\
\hline 1 & Aundh & 0 & 2 & 0 & 3 & 3 & 26 & 34 \\
\hline 2 & Kothrud & 0 & 1 & 0 & 0 & 0 & 22 & 23 \\
\hline 3 & $\begin{array}{l}\text { Ghole } \\
\text { Road }\end{array}$ & 0 & 11 & 0 & 4 & 0 & 35 & 50 \\
\hline 4 & $\begin{array}{l}\text { Warje- } \\
\text { Karvenag } \\
\text { ar }\end{array}$ & 1 & 11 & 0 & 0 & 0 & 15 & 27 \\
\hline 5 & $\begin{array}{l}\text { Dhole } \\
\text { Patil Road }\end{array}$ & 0 & 4 & 0 & 24 & 0 & 34 & 62 \\
\hline 6 & Hadapsar & 0 & 9 & 0 & 3 & 0 & 44 & 56 \\
\hline 7 & $\begin{array}{l}\text { Nagar } \\
\text { Road }\end{array}$ & 0 & 4 & 2 & 0 & 1 & 6 & 13 \\
\hline 8 & $\begin{array}{l}\text { Sangamw } \\
\text { adi }\end{array}$ & 0 & 20 & 0 & 0 & 0 & 33 & 53 \\
\hline 9 & $\begin{array}{l}\text { Bhavani } \\
\text { Peth }\end{array}$ & 2 & 4 & 0 & 0 & 0 & 56 & 62 \\
\hline 10 & $\begin{array}{l}\text { Kasaba- } \\
\text { Vishramb } \\
\text { augwada }\end{array}$ & 0 & 0 & 0 & 0 & 0 & 12 & 12 \\
\hline 11 & $\begin{array}{l}\text { Sahakarna } \\
\text { gar }\end{array}$ & 1 & 3 & 1 & 0 & 0 & 22 & 27 \\
\hline 12 & $\begin{array}{l}\text { Tilak } \\
\text { Road }\end{array}$ & 1 & 0 & 0 & 0 & 0 & 41 & 42 \\
\hline 13 & $\begin{array}{l}\text { Bibvewad } \\
\text { i }\end{array}$ & 1 & 1 & 0 & 0 & 0 & 9 & 11 \\
\hline 14 & $\begin{array}{l}\text { Dhankaw } \\
\text { adi }\end{array}$ & 2 & 2 & 0 & 0 & 0 & 1 & 05 \\
\hline & Total & $\mathbf{8}$ & $\mathbf{7 2}$ & $\mathbf{3}$ & $\mathbf{3 4}$ & $\mathbf{4}$ & $\mathbf{3 5 6}$ & $\mathbf{4 7 7}$ \\
\hline
\end{tabular}

Source: MASHAL, 2011

Table 2. Land Ownership Status of Slum Pockets

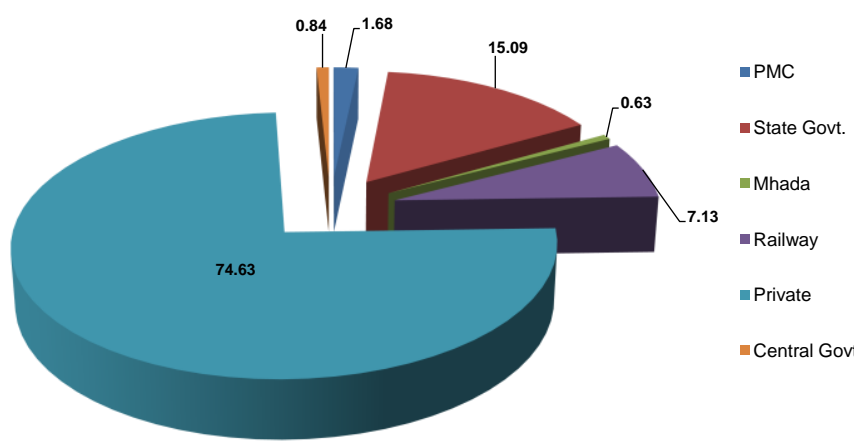

Source: MASHAL, 2011

Figure 9. Land Ownership-wise Distribution of Slums

Figure 10 shows that some slums tenements are located in critical locations which need to be relocated to safer areas in order to develop these locations and also in the interests of the safety of slums dwellers. In Pune city, more than 200 slums are located near environmentally sensitive area and more than 3 ,
80,000 slum populations live in these slum pockets. The builtup area encroachment activity and vulnerable slum areas majorly observed in newly added area in PMC limit, i.e. Ambegaon Bk., Vithhal Nagar and Warje, etc.

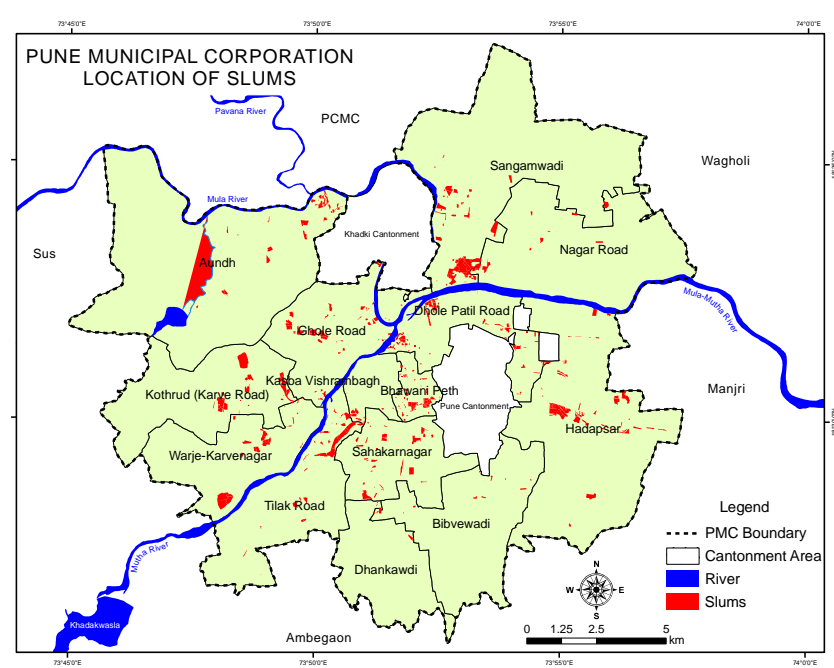

Figure 10. Slum locations in Pune

Note: Areas highlighted in red indicate slum areas. Pune and Khadki Cantonment Board ( $P C B$ and $K C B$, respectively) are not included in the study area.

\section{RECOMMENDATIONS}

- There should be proper check and control by the government over vacant lands, and at the same time, people squatting on such lands should be provided affordable housing options.

- Slums located in the most environmentally sensitive and disaster-prone areas should be given priority in the provision of housing, specially focused on peripheral areas of Pune city like Warje, Ambegaon Bk and Vithhal Nagar, etc.

- Slums which will be resettled should be placed within a distance of $1.5 \mathrm{~km}$ preferably; so that the slum dwellers do not lose their livelihood.

- Zoning/Reservation of a certain percentage (10\% to $20 \%$ ) of land for Economically Weaker Sections (EWS) and Low Income Group (LIG) housing.

- Creation of housing stock of smaller size tenements (200 500 sq.ft.).

- Prevention of illegal settlements in the future.

- Slum-dwellers should be sensitized about the small family size through workshops and other measures.

- A vision of slum-free city can be achieved through implementation of Rajiv Awas Yojana, BSUP schemes, policies for Slum rehabilitation/redevelopment schemes through SRA rules and D.C. regulations.

\section{CONCLUSIONS}

In this research work, identifying and mapping of slums might be one of the most challenging tasks for all metropolitan cities due to rapid growth of population and speedy migration. Planning controls are usually ineffective in slum areas due to lack of timely information and people having little regard for 
such things in the absence of any other alternative. Thus the main contribution of this study is the quantification of uncertainties related to slum and mapping of slum areas using Geospatial tools like remote sensing and GIS techniques.

Remote sensing data may be used for a rapid inventory of the location and physical composition of slums. In this study, various methods like image rectification, enhancement classification, and accuracy assessment are used because of more flexible, accessible and accurately deal with the large variability in slum areas. The present research work also identified vulnerable slum areas using various factors like growth of slum population, slum population density, tenement density, and location of slums, etc. These findings of the work are expected to achieve the Million Development Goal of a slum-free city, measures to control future slum growth and eradicate the slums as well as minimizing impacts on the environment.

\section{ACKNOWLEDGMENTS}

I thank the Department of Geography, Sir Parashurambhau College, Pune for providing laboratory facilities. We express profound gratitude to Dr. Dilip N. Sheth, Principal, Sir Parashuramhau College, Pune. The author also thanks Prof. R. B. Bhagat, International Institute for Population Sciences, Mumbai for their advice and encouragement. The author also thanks to Dr. Ashok Chaskar, Dr. Sunil Gikwad, Dr. Manojkumar Devne, Dr. Suresh Deshmukh, Dr. D. B. Pawar, Dr. Nitin Ade, and Shri. Ganesh Dhawale for careful reading, insightful comments, and suggestions.

\section{ABBREVIATIONS}

ASTER: Advanced Spaceborne Thermal Emission and Reflection Radiometer; ESR: Environmental Status Report; EWS: Economically Weaker Sections; GDEM: Global Digital Elevation Model; GIS: Geographic Information System; GPS: Global Positioning System; IIPS: International Institute for Population Sciences; ISRO: Indian Space Research Organisation; KCB: Khadki Cantonment Board; LIG: Low Income Group; LISS: Linear Imaging Self Scanning Sensor; MHADA: Maharashtra Housing and Area Development Authority; NRSC: National Remote Sensing Centre; OSM: Open Series Map; PCB: Pune Cantonment Board; PMC: Pune Municipal Corporation; RS: Remote Sensing; SOI: Survey of India; SRA: Slum Rehabilitation Authority; USGS: United State Geological Survey; UTM: Universal Transverse Mercator

\section{REFERENCES}

Arveti, N., Etikala, B., \& Dash, P., 2016: Land use/land cover analysis based on various comprehensive geospatial datasets: A case study from Tirupati area, South India. Advances in Remote Sensing, 5, 73-82.

Behanzin, I. D., Thiel, M., Szarzynski, J. and Boko, M., 2015: GIS-Based Mapping of Flood Vulnerability and Risk in the Bénin Niger River Valley. International Journal of Geomatics and Geosciences, 6(3), 1653-1669.

Census of India, 2011; Government of India.

Cohen, J., 1960: A coefficient of agreement for nominal scales. Educational and Psychological Measurement, 20, 37-46.
Congalton, R. G., Green, K., 2008: Assessing the accuracy of remotely sensed data: principles and practices. $2^{\text {nd }}$ Edition, CRC Press, Taylor \& Francies Group.

ESR, 2016-17. Environmental Status Report, Pune Municipal Corporation, Pune.

https://www.pmc.gov.in/sites/default/files/reports_dpr/ESR $\% 20$ 2016-17.pdf

Government of India, 2013: Census of India 2011.

Jensen, J. R., 2004: Remote Sensing of the Environment: An Earth Resource Perspective, University of South California.

Jensen, J. R., 2005: Introductory digital image processing: a remote sensing perspective. Pearson Prentice Hall: Upper Saddle River, NJ.

Jitendra, K., 2014: Slums in India: a focus on metropolitan cities. International Journal of Development Research, 4 (2), 388-393.

Joshi, P., Sen, S., Hobson, J., 2002: Experiences with surveying and mapping Pune and Sangli slums on a Geographical Information System (GIS).

https://doi.org/10.1177/095624780201400218

Kombe, W. J., 2005: Land use dynamics in peri-urban areas and their implication on the urban growth and from: the case of Dares Salaam, Tanzania. Habitat International, 29, 113-135.

Lillesand, T. M., Kiefer, R.W., Chipman, J.W., 2000: Remote Sensing and Image Interpretation. $4^{\text {th }}$ Edition, John Wiley, New York.

Maktav, D., Erber, F. S., 2005: Analysis of urban growth using multi-temporal satellite data in Istanbul, Turkey, International Journal of Remote Sensing, 26(4), 797-810.

MASHAL, (2011). Pune Slum Atlas.

Mishra, A. K., Deep, S., Choudhary, A., 2015: Identification of suitable sites for organic farming using AHP and GIS, The Egyptian Journal of Remote Sensing and Space Sciences, 18, 181-193.

NRSC/ISRO, 2015: Manual on "Bhuvan Geospatial Content Standards".NRSC-RSAA-USGIG-AUG-2015-TR-729.

Ooi, G. L., Phua, K. H., 2007: Urbanization and Slum Formation. Journal of Urban Helath, 84(1), 27-34.

Sori, N. D. 2012: Identifying and classifying slum development stages from spatial data. Thesis submitted to the Faculty of Geo-Information Science and Earth Observation of the University of Twente, Enschede, The Netherlands.

Sur, U., Jain, S., Sokhi, B. S., 2004: Identification / Mapping of slum environment using IKONOS satellite data: a case study of Dehradun, India.

http://www.geospatialworld.net/article/identification-mappingof-slum-environment-using-ikonos-satellite-data-a-case-studyof-dehradun-india/

Shekhar, S., 2012: Detecting slums from Quick Bird data in Pune using an Object-Oriented Approach. International Archives of the Photogrammetry, Remote Sensing and Spatial Information Sciences, 39(B-8), 519-524. 
United Nations, 2011: World Urbanisation Prospects, 2011

revision, Population Division, United Nations, New York. 